\title{
Trust as \\ a factor activating implementation abilities - from theory to practice of a flexible company'
}

"I always knew that I would have close business associates...

that we would stick together and grow together no matter what happened."

Bill GATES

\section{Introduction}

Globalisation and the new economy impose more and more new requirements on companies and entrepreneurs (Borowiecki 2016, p. 48). The companies were forced not

Prof. Bogdan Nogalski, honorary doctorate WSB University in Gdańsk, Faculty of Finance and Management Institute of Management and Finance Przemysław Niewiadomski Ph.D., Eng. Poznań University of Technology, Faculty of Engineering Management, FORTSCHRITT only to create and search for creative, adaptive, and anticipative enterprises towards a more turbulent environment, but also to such systemic reconstructionand structuralchanges in their tangible and intangible assets, which will enable them to develop. Accordingly, the activities of companies pose many challenges also in the area of trust management ${ }^{2}$.

1 This paper refers to a manufacturing company related to the production of spare parts and components for agricultural machinery; such institutions constitute a subject of the authors' current and future research. In the opinion of the authors, the company subjected to the research is a flexible organisation that through its structure and management process - under conditions of emerging market opportunities - quickly and seamlessly activates its resources in order to generate value for the client.

2 In this paper, it was assumed that the trust should be considered as a capital, which is as important as a financial or knowledge capital. Even the possibilities of supplementing shortage of physical or financial resource by increasing trust as a factor giving a good chance to improve the performance of companies are suggested. 
The assumption in relation to this concept is the belief that no combination of resources and competences of an organisation guarantees a sustainable competitive advantage, which results in the organisation's continued search for the new, rare resources and competences (or new combinations of resources and competences) adapted to the changing environment. In other words, it must be stated that the acceptance of the variability of the environment is the basis of the concept of trust management in every organisation. More and more modern management techniques and practices are based on the involvement of partners in the functioning of the organisation. The goal is to appropriately use their skills and possessed knowledge ${ }^{3}$, which serves, among others, better addressing the needs, innovation of the company ${ }^{4}$, improved activities within the organisation. As a result of the wide recognition of the importance of trust as an element related to the cooperation in a variable and hardly predictable environment, the trust was appreciated by management sciences. Building trust in the organisation plays an important role. Trust facilitates the management, risk-taking, effective use of resources, as well as impacts all activities of the organisation. Thanks to the trust, the organisation can react quickly to changes in a complex and turbulent environment, in which it is necessary to develop new - adequate to the needs products.

In the context of the above, the research, whose implementation was conditional to attempt to answer the following question, was begun ${ }^{5}$ is the quantity of products implemented by the manufacturer a derivative of trust developed between him/ her and his/her recipients? In the context of such a question, the main objective of the paper is an attempt to illustrate trust - created by the manufacturer - as an attribute promoting his/her implementation flexibility, which is understood as the organisation's capacity to implement new products, for extensive and unexpected changes rapidly occurring in the environment; theseimplementations significantly affect the organisation's results (implementation efficiency). The achievement of such an objective is possible thanks to a detailed case analysis of the selected implementation process, which confirms that good relationships

3 Such techniques of creative thinking as: nominal group technique, brainstorming, Delphi method (Stankiewicz, 1999, p. 69) serve its creation.

4 In the process of creating, they require employee's participation based on creativity (Moczulska, Stankiewicz, 2016, p. 117), especially since attitudes and behaviours should be supplemented with components of creativity (Stankiewicz, Moczulska 2016, p. 37).

5 While proceeding to the studies, it was assumed that the greater the ability to build trust with partners the manufacturer manifests, the higher implementation flexibility level he/she achieves. 
between partners - as a result of the increase in production series - may imply a decrease in its unit costs, which leads to significant profits in the long term.

Therefore, the recommendations - resulting from theoretical reasoning and observations conducted by the authors ${ }^{6}$ - are an important knowledge base, which entitles them to claim that the condition of the development of a manufacturing company is the trust generated by it, which is made a reality with specific implementations.

This publication was created as a result of the authors' reflection and exploration, but primarily their practical actions in the current economic reality ${ }^{7}$.

\section{Trust in the theory and practice of a flexible company ${ }^{8}$}

According to B. Nogalski (2010, p. 300), a modern company is subject to significant changes involving the functioning in a more and more wider institutional perspective, on the increasing discontinuity of development challenges, and on the increasing complexity as a social system. Such an environment requires a flexible reaction to the needs of the market, which is possible with an entrepreneurial mental attitude, which, according to R. A. Baron (2006, pp. 104-109), involves vigilance and active search for patterns by noticing and interpreting, so as to create ideas of new projects.

The change in the environment's dynamics and the nature of events occurring on it as well as the complexity of the related problems is the main cause of the evolution of methods supporting the management process (Skalik 2012, p. 30). It becomes necessary to seek continuous innovation as a factor for building competitive advantage (Skalik, Wierzbic 2013, p. 94). It is important to employ professionals, who can adequately serve the clients and to seek their trust and loyalty. J. Stankiewicz and H. Bortnowska (2011, pp. 18-19) note that they must be not only acquired, but also have their permanent development secured ${ }^{9}$.

6 According to J. Stankiewicz, P. Łychmus, and H. Bortnowska (2011, p. 582), it is necessary to apply theory into practice and provide managers with management instruments.

7 G. Bełz, P. Malinowski and Z. Olejczyk (2013, p. 22) postulate that mechanisms of cooperation between the most widely understood scientific and research communities, ensuring the transfer of knowledge to companies, are needed very urgently. This view is shared by the authors of this publication, which is manifested by the presented research conducted for the needs of and with the participation of "practice."

8 In this publication, the trust is analysed as an important determinant of the management of the organisation flexibility.

9 In this process, the dominant role is played by the employees' creativity. Therefore, the conditions for its support must be provided as well as the opportunities to its triggering through internal competition must be sought (Stankiewicz, Moczulska, 2013, p. 123). 
The success of the organisation ceased to be an exclusive merit of skilful placement and use of capital. Among practitioners, the belief that the competitive advantage is achieved with unique solutions, which are considered as a resource in a given company, strengthens. A product portfolio built by the manufacturer, expressing with the products' matching to the indicators resulting from the environment, including the consumers' demand, may be such a resource. Because of the high saturation of the market and quickly changing environment, one needs to know what to produce, how to produce, and to whom, and for how much to sell this product. The manufacturer must make decisions on the type and quantity of the manufactured products, taking into account the economic and non-economic conditions of production.

In the view of the above, it is noted that the most valuable skill for modern organisations becomes, therefore, the ability to dynamically create and implement new products and solutions. Therefore, the question is: which features of a company decide about its dynamic implementation potential? The conversations and studies conducted by the authors qualify them to claim that in the flexibility management process, trust between partners is very important ${ }^{10}$. It strengthens the ability to change and supports radical changes. Trust impacts innovation activities, supports creativity. Trust enables the control of tacit knowledge, which is impossible to control through formal mechanisms due to its uniqueness and a small codification degree. Trust also stimulates the processes of learning by generating social ties, which are informal communication channels, extending the range of perceived responsibility or enlarging the area of potential learning opportunities. In view of the above, it is not surprising that in the last several dozen years, the question of trust has focused the attention of many researchers and columnists. In addition to sociologists, for whom this topic remains a major area of interest, also theoreticians and practitioners of management, political scientists, economists, and psychologists deal with the topic of trust. This explosion of interest has occurred because of an unprecedented (caused by, among others, globalisation) occurrence of huge areas of uncertainty and risk, further enhanced by the last, still smouldering general economic crisis (Zieliński 2012, p. 74).

Within the conducted study of the subject literature, the authors verified the selected ways to interpret trust ${ }^{11}$. Their considerations allow you to state

10 Under these conditions, trust becomes necessary non-tangible asset of the company that generates value.

11 Within the framework of the conducted studies, the literature of Polish authors, among others: Czakon (2015), Romanowska, Trocki (2002), Nieścior (1999); Grudzewski, Hejduk, Sankowska, Wańtuchowicz (2009); Zieliński (2012); Lewicka, Zakrzewska-Bielawska (2016); Paliszkiewicz

61

BOGDAN NOGALSKI

PRZEMYSŁAW NIEWIADOMSKI 
clearly that this term is a multidimensional concept, which causes difficulties in its explicit interpretation both by the authors representing the management sciences and related sciences ${ }^{12}$. Defining trust is like specifying many other key categories or concepts in the field of economics or management. There is a multitude of definitions; there is a lack of uniformity. Consequently, this leads to different interpretations of the concept. To sum up, it should be pointed out that:

- the term "trust" is a multi-faceted and complex concept, which causes difficulties in its clear defining and interpreting; there is a multitude of definitions ${ }^{13}$,

- most of the definitions are combined with the common element in the form of linking the trust phenomenon with people's actions (Fukuyama 1997, p. 38; Sztompka 2007, pp. 155-157),

- trust is a term strongly associated with ethics and morality (Moczydłowska 2013, p. 93),

- trust can be seen from different points of view, seeing it both within a single organisation (e.g., between employees, of an employee in the management), and between organisations,

- In the literature on organisational behaviours, trust is treated in two ways; in the first approach, trust is a characteristic of the duration of a relationship, indicating its quality; in the second one, it is a determinant, which is a condition of partnership,

- the literature indicates the behaviours characteristic fr high or low level of trust,

(2011b) Bugdol (2010); Paliszkiewicz, Koohang, Gołuchowski, Nord (2014); Sztompka (2007); Sankowska (2011); Paliszkiewicz (2013); Sztompka (1998); Paliszkiewicz (2011a); Sztompka (1999); Jończyk (2009); Lewicka-Strzałecka (2003) - as well as foreign ones: Solomon, Flores (2001); Gilberth, Tang (1998); Chiles, McMackin (1996); Paliszkiewicz, Koohang, Nord (2014); Zand (1972); Zaheer, McEvily, Perrone (1998); Gulati (1995); Handy (1995); Shapiro (1987); Covey, Merrill (2008); Lewis, Weigert (1985); Covey, Merrill (2009); Hardin (2002) - was reviewed.

12 Therefore, an important task is to focus the scientific community on the business practices, including joint research and conferences related to the trust management in terms of topic. In Poland, such initiatives are taken by, among others: the Department of Human Resources Management in Organisations, which under the leadership of Professor J. Stankiewicz, organises recurring conferences titled "Nowoczesne Zarządzanie Przedsiębiorstwem" [in Polish: Modern Company Management]. Within meetings, a thematic area concerning conditions of companies and interorganisational networks is forecast.

13 An interdisciplinary approach to the issue of trust causes different understandings and definitions of this the term (Lewicka-Strzałecka, 2003, p. 197). 
- the researchers refer most often to the resource based view and to the transaction cost theory, which may constitute a framework to explain the nature of the conditions for the formation of relational associations and their conditions,

- in the issue of the interpretation concept, the transfer of scientific achievements from other countries or sciences without a clear mark of origin and meaning of these definitions is observed,

- some authors consider trust and social capital as identical concepts (Fukuyama, 1997), others believe that trust is the source of the social capital (Putnam), and some others that it is its component (Coleman, 1988) ${ }^{14}$,

- the theory and practice of management shows that one definition of trust is far from common acceptance ${ }^{15}$,

- despite the internal diversity of the definitions, we can distinguish the following trust characteristics (Paliszkiewicz, 2013): is voluntary; results from personal choice, always refers to someone or something, has a defined area and level, is associated with concern about the honesty of both parties, is dynamic and temporary, develops over time, increases or is interrupted, is based on experience, is associated with expectations for the future, is the foundation of social interactions, exists in an environment of uncertainty and risk, is a concept of a positive nature (Illustrated Oxford Dictionary 1998, p. 893; Grudzewski et al. 2009, p. 20),

- the opposite of trust is distrust understood as suspicion about the lack of honesty or skills ${ }^{16}$,

- as a result of the wide recognition of the importance of trust under conditions of a variable and hardly predictable environment, it was appreciated by management sciences,

- a methodological confusion undoubtedly occurred, which sometimes leads to conflicting opinions, and even disputes about what trust is in fact, and thus -

14 W. Dyduch (2004, p. 48-55), while researching the components and dimensions of the organisation's social capital, stated that trust is one of the components of the social capital, which is the least important though.

15 The search for one, common, or universal definition would enrich neither the knowledge nor practice of management and, at the same time, could lead to a narrowing of the field of research; the authors recommend such definitions that make sense in the context of the organisation conditions and can be used consistently in the conducted research.

16 It manifests itself in a lack of impartiality and honesty in relation to the partner, in order to achieve benefits for oneself at the expense of others (Wojcik-Karpacz, Karpacz 2015, pp. 169-170). 
what methods to use when researching it ${ }^{17}$; Since the term "trust" often occurs both in colloquial thoughts and scientific studies, it was necessary to analyse and adopt own definition.

In the context of the review of literature and on the basis of the practical experience of the authors - for the needs of research - the following assumptions were adopted as leading:

- trust has a positive economic dimension ${ }^{18}$, it is a resource resulting from the needs or systematic observation of the market,

- it refers to a product, an opportunity of its implementation; whereas the product is perceived as new by the manufacturer,

- the skill to establish permanent relationships with the environment is the guarantee of success on the more and more competitive and variable market,

- building a competitive advantage must be based on mutual trust between the partners and the companies' ability to create them effectively.

Without attempting to quote different views on the nature of trust, to the most generalised extent, it can be assumed that trust involves trusting in the abilities and competences of other party of the relationship. In other words, trust is the expectation that one can rely on the partner, that he/she will fulfil his/ her commitments in a predictable way, and that he/she will work honestly in the face of various opportunities ${ }^{19}$. Trust determines the competitive advantage, reduces the cost of control, and has tolerance conditioned by innovation ${ }^{20}$ and independence of action ${ }^{21}$.

17 Thus, a need for research in this area is born. Against the methodological shortcomings in terms of the measurement of trust, A. Rudzewicz's (2016) attempt to measure the intraorganisational trust directly and A. Sankowska's (2009) diagnosis of the level of trust between companies should be noted. The new direction of the measurement of trust and its valuation in the context of activation of implementation processes of a manufacturing company is currently the subject of the research team of scientists led by B. Nogalski.

18 The positive economic dimension means that trust must bring a measurable benefit, which - in this case - is the opportunity to develop the product portfolio by the manufacturer.

19 W. Czakon $(2008$, p. 376) similarly sees trust by writing that it means positive expectation of a partner's specific behaviour under risk.

20 J. Stankiewicz and M. Moczulska (2013, p. 119) postulate that one of the most important competition instruments of companies includes innovations.

21 The entities involved in innovation activities because of the large scale of risk need trust (Loon Hoe, 2007, pp. 149-156).

Trust as a factor activating implementation abilities - from theory to practice of a flexible company 


\section{Trust and implementation flexibility - relationship matrix}

Trust is usually associated with a human characteristic close to naivety but also kindness, and even benignity. Meanwhile, trust is a designate of modern organisation and its domain. It is also an attitude that must lead to certain behaviours. This debunks one of the myths about trust that it depends entirely on the other person. In terms suggested the authors of this work, trust is associated with an organisational culture, the organisation's vision, as well as attitudes, management style, and leadership. Trust is the strongest stimulus catalysing commitment and innovation. When it is skilfully implemented, it builds cooperation allowing to accomplish long-term implementation goals.

In terms of management adopted by the authors, trust translates into the company's implementation flexibility. Therefore, one of the main tasks of the responsible business policy is to build, regain, or maintain the trust of partners - clients. However, there is a view that negates the reasoning described above. There are many voices from both the academia environment and the business world denying the importance of trust in the organisation (fig. 1). The intentions of the organisations' managers, for whom the only way to success is to maximise a short-term profit, are subjected to doubt.

Here, it should be emphasised that the market situation, in which the company operates, determines its behaviour. Small companies, operating under competitive conditions, will behave in a way that is completely different from the one of the monopolistic companies dominating on the market. The behaviour of the companies on the market is reflected by, among others, their decisions on the size and structure of production, which in turn affect the implementation flexibility achieved by these companies.

Trust depends on the expectations, experiences, situational factors, work organization, and emotional states. Situational factors, organisational, and psychosocial as well as lack of motivation may decrease or increase trust, hence sometimes high trust level determines low flexibility.

No relationship between trust and implementation flexibility of the organizations (the I matrix quadrant illustrates the situation) can be explained only with a favourable circumstance, a temporary (one-off) opportunity. According to the development's authors, the presented dependence is practically possible, but is extremely rare. It can be a momentary advantage over other market participants; in no case may it be a basis for planning the company's long-term activity, unless - pro-developmentally thinking - the company uses the "accidentally" achieved means rationally. Nonetheless, it all comes down 
anyway to the fact that long-term relationships built on trust are ultimately key in the context of the further activity and development of the company. In this situation, the reaction should be very quick. It is a very simple and well known principle but difficult to be implemented because in a crisis situation, people subjected to pressure, in order not to make a mistake, usually gather more information before making any decision. Meanwhile, in emergency situations, quick action communicates decision-making and care. If someone is visible and reactive, he or she sustains trust more effectively than when he or she is thinking what to do.

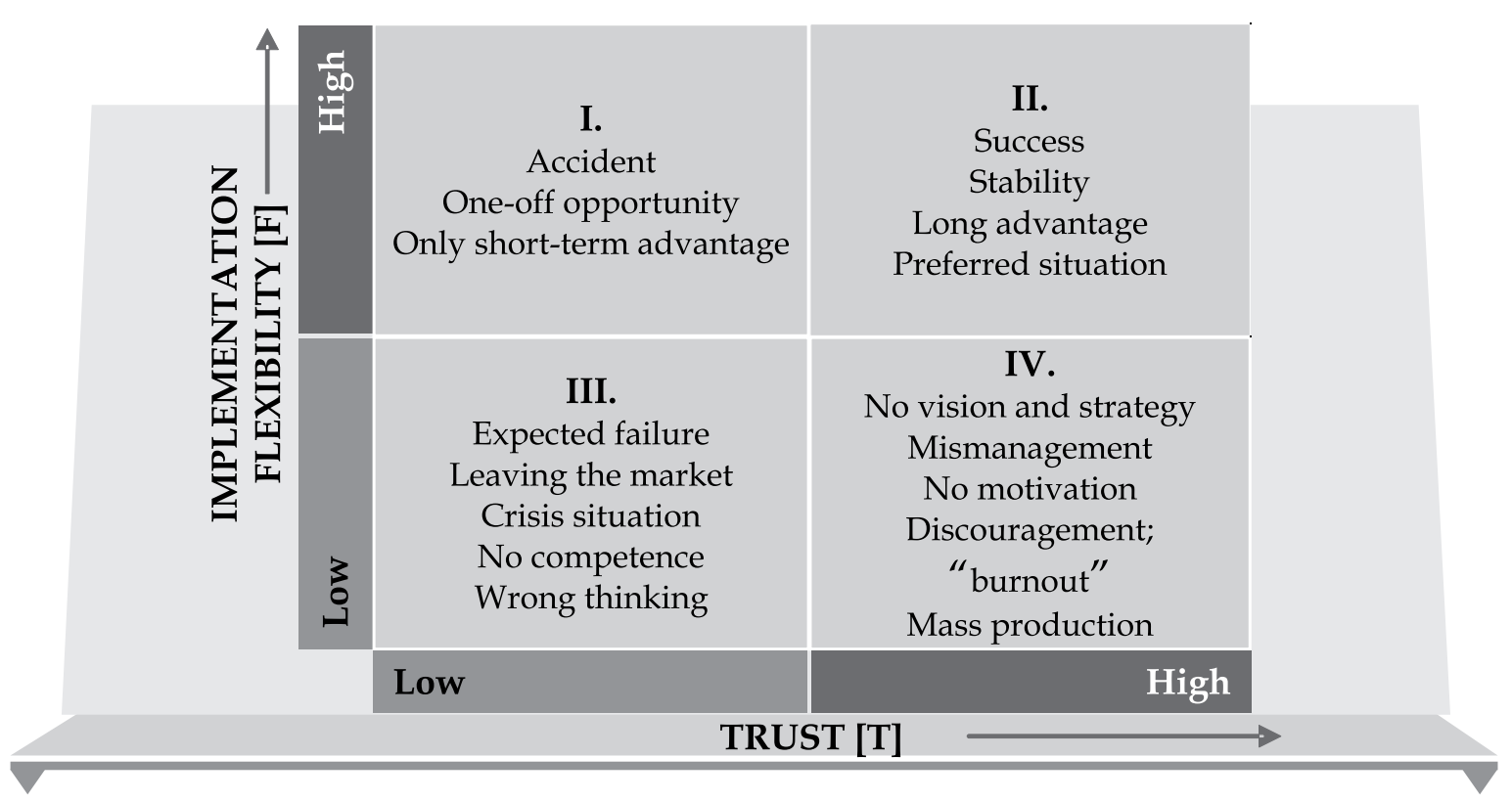

Figure 1. Flexibility and trust relationship quadrant

Source: own development

Referring to the IV quadrant - illustrating a situation, in which developed trust does not translate into an increase in the implementation flexibility - it must be stressed that such a situation may be the result of the company's lack of interest in developing such a relationship. No vision and strategy, poor leadership, or loss of motivation for further development are the circumstances that encourage this. Such a situation occurs very rarely. Situations in which there is relationship between the - developed for years - trust and the implementation relationship

Trust as a factor activating implementation abilities - from theory to practice of a flexible company 
are more often. The II matrix quadrant shows the system of such a relationship. This is a situation that guarantees the stability of functioning of the manufacturer on the market, which is further described in this paper.

The above content leads to formulating the following conclusion: the higher level of mutual trust between the entities is, the higher probability and ability of implementing a product adequate to the real needs of the market are. It must be noted, however, that trust and the ability of its continuous "nurture" is only one of the conditions for achieving a certain level of implementation efficiency.

\section{Trust and implementation flexibility in practice of an AMS company ${ }^{22}$ - attempt to assess}

\subsection{Research scope and subject}

One of the factors determining the success in the business activity is trust generated by it. In the business world, there is a relationship between trust and long-term benefit of an organisation in the form of a profit. This is indicated by numerous studies conducted by the development's authors. They show that the above-average demands regarding the issue of trust correlate positively with above-average economic results achieved by the company. Hence, the management practitioners' growing interest in the issue of trust and their search for recipes for skilful implementation of this concept. The theorists address these expectations, which is reflected in the Polish subject literature - the increase in the authors' interest in the issue of trust in management is noticeable. The search for paradigms based on broad understood trust in business, cannot, however, be reduced only to the theoretical issues. It is necessary to apply theory to practice and to provide managers with instruments of management of ethics in an organisation, which is reflected by the research conducted by the authors.

The research referred to in this part of the development was conducted from the perspective of a Polish manufacturer of parts for agricultural machinery; they concern a specific - occurred in a company - case ${ }^{23}$. The purpose of the research was to present trust developed by the company as an attribute favourable for using an opportunity and, ultimately, increasing its implementation flexibility. The research subject was a case of implementation of a cam disc number $64757729500 \mathrm{~F}$ (fig. 2) into production.

22 AMS is an abbreviation for "agricultural machinery sector".

23 The selection of the case under assessment was intentional.

67

BOGDAN NOGALSKI

PRZEMYSŁAW NIEWIADOMSKI 


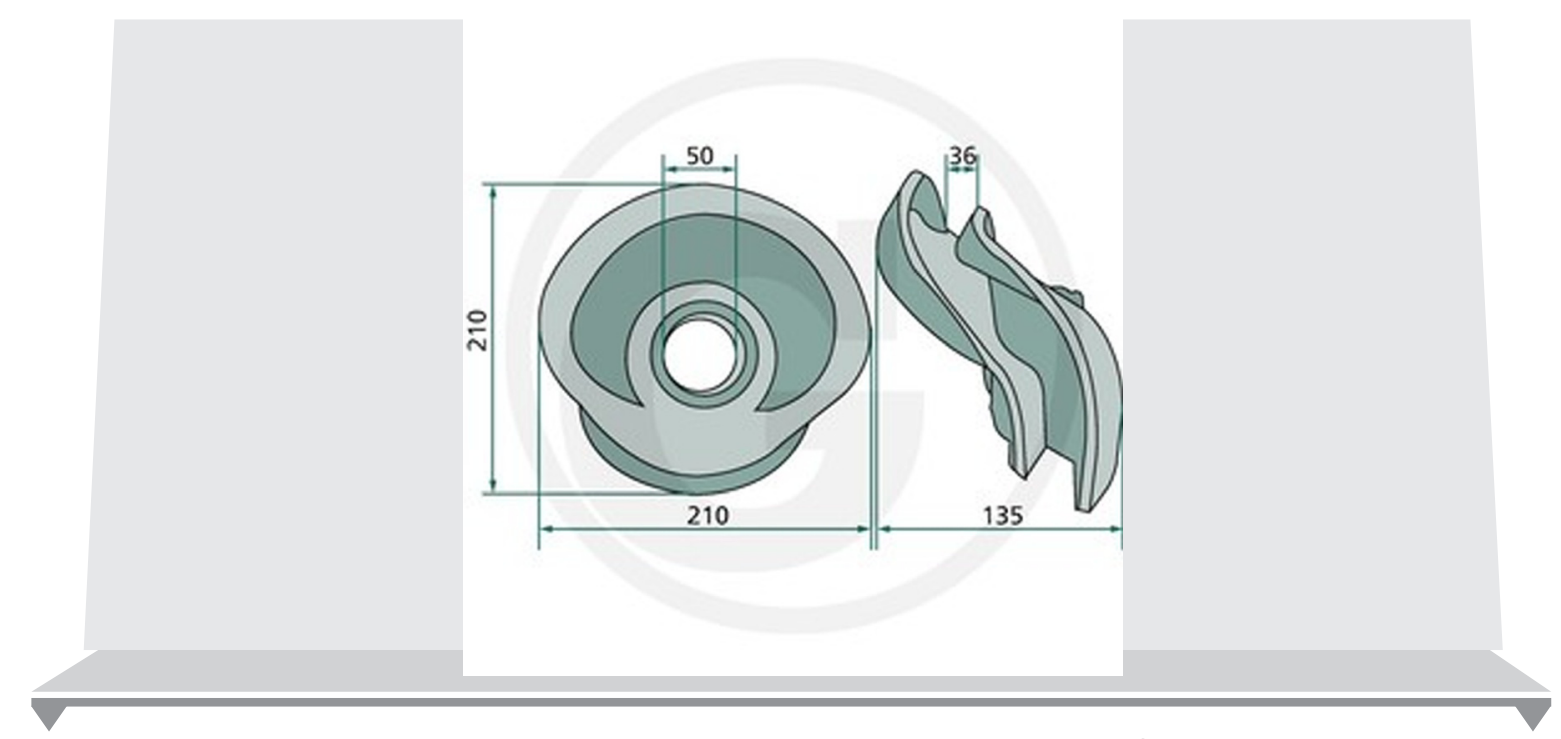

Figure 2. The $64757729500 \mathrm{~F}$ cam disc - the object of the analysis in the context of trust

Source: in-house media of Granite Parts

On the basis of an inquiry, that the company received from its current customer, the authors intended to illustrate the course of implementation in the context of trust - determining the said process - between the parties of the transaction ${ }^{24}$.

The company's success is influenced by many different factors, and one of them is mutual trust between the business partners, about which it can be said in the context of the studied companies. This translates into the partner's involvement and satisfaction with the cooperation. As a result, this has an impact on the financial results of each of the parties.

\subsection{Case study}

In the framework of the long-term cooperation with Granite Parts Polska ${ }^{25}$, the manufacturer, referred to in this work, received an inquiry regarding

24 The relationships are based on mutual trust.

25 The company leading wholesale of original and spare parts for most brands of agricultural machinery present on the global market. The centre of GRANIT's operation is in the central warehouse in Heeslingen, whereas sister companies are in Austria, the Netherlands, Belgium, France, Italy, England, Poland and Czechia, Denmark, Switzerland, and Hungary. More: www. granit-parts.pl.

Trust as a factor activating implementation abilities - from theory to practice of a flexible company 
a possibility to implement - intended for the KUHN machine ${ }^{26}$ - the cam disc number $64757729500 \mathrm{~F}$ (fig. 2). The inquiry was sent by e-mail to the manufacturer on 25-01-2017. Due to the seasonality of the market ${ }^{27}$ and the relatively low level of sales of the product ${ }^{28}$, the order was placed for only 50 pieces of the product. In the above context, the research on process of disc production was commenced; resource requirements, including the means and subject of labour, were estimated, as well as the necessity of process operations was specified ${ }^{29}$.

The basis of the development of a given part's production process is its shape that is size and complexity degree as well as the material, of which is to be executed. In the case of the disc, the starting material was ductile iron. In the context of the above - with the participation of a process engineer-caster, it was agreed that it is necessary to produce a special model ${ }^{30}$ for the production of an iron casting, which - at a later stage - will undergo removal treatment ${ }^{31}$. The conducted simulation allowed to estimate the cost of manufacturing of a casting pattern; method of rapid prototyping was used ${ }^{32}$, and in order to execute a casting, a sand mould process was chosen. Within executed activities, it was agreed that the production cost of the casting pattern - for the analysed kind of disc - is at the level of EUR 2,100.00 to EUR 2,350.0033. Taking into account the supply of 50 pieces of the product at the sale price of EUR $58.00^{34}$ and the production costs

26 For over 40 years, KUHN has been a leader in the production of hay-making equipment, among which mowing machines, tedders, and rakes stand out. More: www.kuhn.com.pl 27 Despite the hay-making equipment is necessary in a farm, it is not used for an entire year. By analysing the specifics of the seasonal work, the demand for the spare parts for it can be specified.

28 As this is a new item in the recipient's product portfolio, the market research was conducted. The preliminary analyses gave reasons to believe that in 2017, the demand for a replaced product can be only at the level of 20-30 pieces.

29 The research - in which the authors of this works also participated - was conducted in Fortschritt's headquarters in Września near Poznań.

30 It is an instrument, which is used for mapping the external shape of the casting in the mould.

31 The aim of the removal treatment is removal of specified material volume.

32 The method for fast, precise, and repeatable production of items in the additive process (e.g. using 3D printing techniques), usually computer-controlled.

33 Total production costs include: 1) the development of three-dimensional casting process using computer aid (image editors, computer simulations), 2) the development of virtual models and documentation of foundry equipment, 3) making of casting patterns (a match plate), 4) making moulds on the basis of the casting patterns, 5) smelting of chosen foundry alloy 6) pouring moulds, cooling and tripping casting moulds, cleaning castings, cutting gatings and fuel systems, 7) painting.

3450 pcs. $x$ EUR $58.00=$ EUR 2,900.00. 
related to its implementation ${ }^{35}$, it was agreed that the manufacturer achieves a loss of EUR $120.00^{36}$.

In the context of the presented situation, the manufacturer had to decide whether and possibly how to meet the expectations of the recipient and the market. Whether to undertake the production or perhaps - as a result of unprofitable implementation of 50 pieces of the disc - decline the contract. In fact, it would have a negative impact on sales results binding the partners. Acquiring a new supplier costs several times more than the expansion of cooperation with the current one; it takes time and is associated with high risk ${ }^{37}$. This makes the operation of the companies must be changed, and succeeding on the market requires completely new rules. Trust in the partner turns out to be more important than the focus only on sales. Creating friendly relationships between suppliers and recipients becomes an indispensable value of the company, and the built trust is a derivative of success, which the presented case confirms.

Due to trust and long-term relationships biding the partners, the search for a solution - under which, at the sale price imposed from the top - the minimum quantity that could provide the implementation effectiveness assumed by the manufacturer was specified.

Thanks to the good cooperation between the parties based on mutual trust as a result of negotiations and mutual arrangements - the target order, which the buyer would declare, was increased to 100 units of the product ${ }^{38}$; whereas

35 The costs of raw material purchase (a casting of ductile iron) - EUR 8.70, labour costs - EUR 4.70 , and additional implementation costs - related to the execution of the casting pattern - at EUR 2,350.00 were taken into account.

36 The sum of the incurred costs is EUR 3,020.00, including one-off costs of the equipment and model - EUR 2,350.00; the raw materials cost of - EUR 435.00 (50 pcs. x EUR 8.70), labour costs - EUR 235.00 (50 pcs. x EUR 4.70).

37 The higher supplier change costs, perceived risk, or greater importance of purchased goods or services from the point of view of the buyer's activities are, the higher level of the recipient's dependence on the purchase sources becomes. An important determinant of the buyers' tendency to develop long-term relationships is the type of a purchased product, which results from the sectoral structure of industrial markets.

38 By assuming, as the basis for forecasting, the cost of executing the pattern as well as the costs associated with the production of one piece of the disc, it was agreed that this is the minimum amount that would have to be executed and delivered - together with the first implementation - to the market. The indicated amount - guaranteeing the sales profit, which fully covers the costs of the implementation of the model and the additional equipment - is rational from the point of view of the development strategy outlined by the manufacturer.

Trust as a factor activating implementation abilities - from theory to practice of a flexible company 
the first term of the delivery of 50 units was set for the first half of 2017, while another 50 units was planned to be purchased in the second half of this year.

Ordering such a quantity of the product in relation to its annual sales forecast - despite the significant costs associated with purchasing and storage ${ }^{39}$ - was consistent with the purchase management strategy adopted by the recipient; therefore, it was possible ${ }^{40}$.

Based on own knowledge on specific behaviours - through all the years of cooperation - the partners could build mutual trust, which made that a strong thread of understanding was formed41. When the trust between the partners is high, the feeling of the transaction risk falls. When both partners believe in each other, they will make every effort to comply with the agreement. They do so because they know that they build their good position in this manner, not only with respect to this particular case, but in the long term.

R. Harding (2002, p. 95) emphasised that trust differs from expectations in that it results from the base of a feeling that the party, in which we trust, takes into account our interest to some extent. In this meaning, trust means the partner's mutual obligation to maintain the relationship's continuity with engaging own resources in the belief that executing common activities will translate into benefits for both partners (Lewicka, Zakrzewska-Bielawska 2016, p. 107).

As ordering the product in this configuration was little efficient for both parties - by treating the implementation as a long-term project - the recipient, of his own, spontaneous initiative, decided to guarantee the manufacturer a contract for further deliveries, while the manufacturer declared not to sell the goods to other partners operating on the market; he assured the exclusivity.

39 They are an essential part of the logistics costs. They materially depend on which part of the inventory is paid from own resources (this concerns the analysed case) and which one is funded externally. It is also very important to estimate all the costs associated with the acquisition of warehouse space and its maintenance, such as lighting, air conditioning, or heating costs. The structure of these costs largely depends on whether the company uses its own building (this concerns the analysed case) or rents a storage space.

40 The logistics costs' components, or the ordering and storage costs, depend inversely on the volume of the placed orders. Indeed, if the company places large orders, the annual costs of, for example, transport are most often lower than in the case of the companies that order more often but in smaller quantities. The lost sales costs related to the unused demand, emerged as a result of lack of goods in stock should also be included here.

41 What elements are important for appearance of this trust? The answer to such a question will be a subject of the authors' separate developments. 
Taking the above into consideration, within the framework of the implementation of the 100 pieces of the disc, the manufacturer achieves the net revenue (declared; remote in time) in the amount of EUR 5,800.00, which, when reduced by the amount of EUR 2,350.00 (the costs of production of the casting pattern), at a given production structure, in the final settlement, gives the profit of EUR 2,110.00.

On the basis of a relational approach, bearing in mind trust between the partners, all the implemented investments must be considered in the long term. This approach makes the implementations, which seem to be completely unfounded at a given moment, justified. While considering the case only in the category of the current profit, the proposed solution is relatively little attractive for both parties. As that is a solution oriented on a long-term cooperation, it will, however, translate into big profits in the long term. In addition, it is a kind of a buffer protecting the manufacturer against the competition; high barriers of market entry discourage its other participants to implement this product, especially since partners, who do not trust in each other that much, will not be able to take such action. By making decisions about the implementation, the manufacturer - by limiting the availability of the products (the exclusivity) - gains even greater loyalty of the recipient. Mutual trust as an element of relational exchange dramatically lowers the need for safeguard mechanisms. The partners of a relational exchange have a strong motivation to maintain trust and good reputation because of a long-term orientation in their mutual relations (Heide 1994, pp. 71-85).

Trust (reliability of the other party) reduces the transaction costs (Chiles, McMackin 1996, pp. 73-99). The transaction costs are associated with uncertainty imposed by the context, in which the transaction is conducted, including the opportunistic behaviour of the other party. This is due to the fact that the entity that trusts in its business partner, recognising him/her as the one, who does not act opportunistically, being guided by trust when making decisions, can save on the transaction costs despite the absence of risk associated with the transaction.

Taking into account the additional demand in the perspective of - at least two years, the manufacturer will generate much higher profits, and the recipient - lower supply costs. The manufacturer does not incur the costs associated with performing a model set again. He/she uses the manufacturing process created within the previous implementation. Taking into account the sales of the disc - at least 50 pieces - the future transaction will generate a profit of EUR 2,230.00. 


\section{Conclusion of and directions for further research works}

Good relationships in business bear trust, and nothing brings as many profits as the economy based on trust. The organisations that can gain it reach results many times higher than these, in whom hardly anyone trusts. The number of the products implemented by the manufacturer, whose production would not be possible without such a relationship between the parties, is the derivative of trust built between the manufacturer and his/her recipients.

The confrontation of the need of trust management among the Polish manufacturers of agricultural machinery parts persuade the authors to ask many additional questions about the subject discussed between them ${ }^{42}$. Above all, it was about finding what is the trust level among the Polish companies. General information on this topic is found partly in the literature, and partly by leading research among the Polish manufacturing companies of the sector under research. It turned out that trust is rarely seen in terms of increase in implementation flexibility. The predominant relationship between the companies is intense competition, very often based on imitation.

Since the Polish companies rarely see mutual trust as a tool helpful in their development, a question about the reasons for this state of affairs appeared. Why is there a relatively low trust level and a low tendency to its creation? The problem turns out to be complex. The research presented in this development do not answer it in a holistic way. The foreign literature takes up some subjects about difficulty in its correct perception by applying the problem, unfortunately, solely to the entire group of companies. There is no answer regarding the management practice. As a result of further literature studies on trust and the confrontation of their results with the situation of the Polish manufacturing companies operating in the agricultural machinery sector, the great importance of this issue is noted. As the results of such analyses would be interesting - both for researchers and the management practitioners - they will be the subject of the authors' further developments.

Managers can build their own styles of trust management in the organisation, which will affect the relationships with external stakeholders. Therefore, it is important to specify relevant moral values, with which the organisation and its employees will comply and will be easily identified by clients. It is necessary

42 It is worth asking a question whether trust is a special case implying the relationships or rather not? 
to conduct further empirical studies bringing the process of creating attitudes towards the pro-development-oriented organisations to the science.

\section{Summary}

Trust as a factor activating implementation abilities - from theory to practice of a flexible company

As a result of the wide recognition of the importance of trust as an element related to the cooperation in a variable and hardly predictableenvironment, the trust was appreciated by management sciences. Thanks to the trust, the organisation can react quickly to changes in a complex and turbulent environment, in which it is necessary to develop new - adequate to the needs - products. In the context of the above, the research was commenced, whose execution was the condition of an attempt to answer the question: is the number of the products implemented by the manufacturer a derivative of trust built between him/her and his/her recipients? In the context of such a question, the main objective of the paper is an attempt to illustrate trust - created by the manufacturer as an attribute promoting his/her implementation flexibility. The achievement of such an objective is possible thanks to a detailed case analysis of the selected implementation process, which confirms that good relationships between partners - as a result of the increase in production series - may imply a decrease in its unit costs, which leads to significant profits in the long term.

Keywords: trust, implementations based on trust, implementation flexibility.

\section{Streszczenie}

\section{Zaufanie jako czynnik aktywizujący zdolności implementacyjne} - od teorii do praktyki elastycznego przedsiębiorstwa

W konsekwencji szerokiego uznania znaczenia zaufania, jako elementu związanego $\mathrm{z}$ kooperacją w warunkach zmiennego i trudno przewidywanego otoczenia, zaufanie zostało docenione przez nauki o zarządzaniu. Dzięki zaufaniu organizacja może szybko reagować na zmiany $\mathrm{w}$ złożonym i turbulentnym otoczeniu, w którym konieczny jest rozwój nowych - adekwatnych do potrzeb - produktów. W kontekście powyższego przystąpiono do badań, których realizacja warunkowała próbę odpowiedzi na 
pytanie: czy ilość implementowanych przez wytwórcę wyrobów jest pochodną - wypracowanego pomiędzy nim a jego odbiorcami - zaufania? W kontekście tak postawionego pytania zasadniczym celem pracy jest próba zobrazowania - wykreowanego przez wytwórcę - zaufania jako atrybutu sprzyjającemu jego elastyczności implementacyjnej. Osiągnięcie tak postawionego celu jest możliwe poprzez szczegółową analizę wybranego przy padku procesu implementacji, w ramach której potwierdza się, że zaufanie pomiędzy partnerami - wskutek zwiększania się serii produkcji - może implikować sytuację, w której następuje spadek jej kosztów jednostkowych, co w perspektywie długoterminowej prowadzi do znacznych zysków.

\section{Słowa}

kluczowe: zaufanie, implementacje bazujace na zaufaniu, elastyczność implementacyjna.

\section{References}

1. Baron R. A. (2006), Opportunity Recognition as Pattern Recognition: How Entrepreneurs "Connect the Dots" to Identify New Business Opportunities, Academy of Management Perspective, vol. 20, No. 1, pp. 104-109.

2. Bełz G., Malinowski P, Olejczyk Z. (2013), Centrum nowych technologii $w$ strategii rozwoju przedsiębiorstw branży komunalnej [Technology Research Center in Municipal Enterprise Development Strategy], [in:] G. Bełz, M. Hopej, A. Zgrzywak-Ziemak (ed.), Wiedza w zarządzaniu wspótczesna organizacja [Knowledge on Modern Organisation Management], Wydawnictwo Uniwersytetu Ekonomicznego we Wrocławiu [Publishing House of Wrocław University of Economics], Wrocław, "Prace Naukowe" ["Research Papers"], No. 299, pp. 9-23.

3. Borowiecki R. (2016), Permanentna restrukturyzacja - wspótczesny paradygmat zarzadzania? [Constant restructuring - a contemporary paradigm of management?], [in:] G. Osbert-Pociecha, S. Nowosielski (eds.), Meandry teorii i praktyki zarzadzania [Meanders of management theory and practice], Wydawnictwo Uniwersytetu Ekonomicznego we Wrocławiu [Publishing House of Wrocław University of Economics], Wrocław, pp. 45-55.

4. Bugdol M. (2010), Wymiary i problemy zarzadzania organizacja oparta na zaufaniu [Dimensions and problems of the management of an organisation based on trust], Wydawnictwo Uniwersytetu Jagiellońskiego [Jagiellonian University Press], Kraków. 
5. Chiles T.H., McMackin J.F. (1996), Integrating variable risk preferences, trust, and transaction cost economics, "Academy of Management Review", Vol. 21.

6. Coleman J. (1988), Social Capital in the Creation of Human Capital, "American Journal of Sociology", Vol. 94.

7. Covey S., Merrill R. (2008), The Speed of Trust - The One Thing That Changes Everything, "Free Press", February.

8. Covey S., Merrill R. (2009), Szybkość zaufania [The Speed of Trust], Dom Wydawniczy REBIS [REBIS Publishing House], Poznań.

9. Czakon W. (2008), Koordynacja sieci - wieloraka forma organizacji [Network coordination - diverse organisation form], "Przegląd Organizacji" [“Organization Review"], No. 9, pp. 7-10.

10. Czakon W. (2015), Niepewność jako antecedencja nawiąywwania wspótpracy sieciowej [Uncertainty as a Network Collaboration Antecedent], "Marketing i Rynek" ["Marketing and Market"], No. 9, pp. 89-97.

11. Dyduch W. (2004), Sktadniki i wymiary kapitału społecznego organizacji [Dimensions and Elements of Organization's Social Capital], "Organizacja i Kierowanie" [“Organization and Management"] 2004, No. 1(115), pp. 47-59.

12. Fukuyama F. (1997), Zaufanie. Kapitat społeczny a droga do dobrobytu [Trust. Social capital versus a path to prosperity], Wydawnictwo Naukowe PWN [Polish Scientific Publishers], Warszawa.

13. Gilberth J. A., Tang T. L. P. (1998), An Examination of Organizational Trust Antecedents, "Public Personnel Management", vol. 27, No. 3, pp. 321-338.

14. Grudzewski W.M., Hejduk I.K., Sankowska A., Wańtuchowicz M. (2009), Zrządzanie zaufaniem w przedsiębiorstwie koncepcje, narzędzia, zastosowanie [Trust management in the company concepts, tools, application], Oficyna Wolters Kluwer business [Wolters Kluwer business Publishing House], Kraków.

15. Gulati R. (1995), Familiarity breeds trust? The implications of repeated ties for contractual choice in alliances, "Academy Management Journal", No. 38, pp. $85-112$.

16. Handy C. (1995), Trust in virtual organization, "Harvard Business Review", No. 73 (3), pp. 40-50.

17. Hardin R. (2002), Trust and Trustworthiness, "Russell Sage Foundation", New York.

18. Heide J.B. (1994), Interorganizational Governance in Marketing Channels, "Journal of Marketing", Vol. 58.

19. Illustrated Oxford Dictionary (1998), Oxford University Press, pp. 893.

20. Jończyk J. (2009), Zaufanie jako fundamentalny czynnik proefektywnościowych relacji $w$ organizacji [Trust as a fundamental factor of efficiency-oriented relationships in an organisation], [in:] A. Wasiluk (ed.), Nowoczesne podejścia do zarzadzania organizacjami [Modern approaches to organisations management], Difin, Warszawa. 
21. Lewicka D., Zakrzewska-Bielawska A. (2016), Rola zaufania w relacyjnej orientacji przedsiębiorstwa [The role of trust in the company relational organisation], [in:] G. Osbert-Pociecha, S. Nowosielski (ed.), Meandry teorii $i$ praktyki zarzadzania [Meanders of management theory and practice], Wydawnictwo Uniwersytetu Ekonomicznego we Wrocławiu [Publishing House of Wrocław University of Economics], Wrocław, pp. 105-127.

22. Lewicka-Strzałecka A. (2003), Zaufanie w relacji konsument - biznes [Trust in a business-to-consumer relationship], "Prakseologia" ["Praxeology"], No. 143.

23. Lewis J.D., Weigert A. (1985), Trust as a social reality, "Social Forces", No. 63 (3), 1985, pp. 967-984.

24. Loon Hoe S. (2007), Is Interpersonal Trust a Necessary Condition for Organisational Learning?, "Journal of Organisational Transformation and Social Change", Vol. 4, No. 2, pp. 149-156.

25. Moczulska M. Stankiewicz J. (2016), Interakcje społeczne sprzyjajace zaangażowaniu pracowników w organizacji - założenia w świetle teorii organizacji $i$ zarzadzania [Social interactions conductive to the employees' involvement in the organisation - assumptions in the light of the organisation and management theory], "Nauki o Zarządzaniu" ["Management Sciences"] No. 2(27), pp. 116-129.

26. Moczydłowska J. (2013), Kategoria zaufania w zarzadzaniu kapitałem ludzkim w jednostkach administracji samorzadowej [Trust in Local Government Units' Human Capital Management], "Optimum. Studia Ekonomiczne" [“Optimum. Economic Studies”], No. 3 (63), pp. 92-100.

27. Nieścior A. (1999), Zaufanie w normach ISO serii 9000 [Trust in ISO 9000 series], "Problemy Jakości" ["Problems of Quality"], No. 9, pp. 23-34.

28. Nogalski B. (2010), Lean Management, [in:] M. Czerska, A. Szpitter (eds.), Koncepcje zarzadzania [Management concepts], Wydawnictwo C. H. Beck [C. H. Beck Publising House], Warszawa.

29. Paliszkiewicz J. (2011a), Trust Management: Literature Review, "Management", Vol. 6 Issue 4, p. 315-331.

30. Paliszkiewicz J. (2011b), Inter-Organizational Trust: Conceptualization and Measurement, "International Journal of Performance Measurement", Vol. 1, 15-28.

31. Paliszkiewicz J. (2013), Zaufanie w zarządzaniu [Trust in management], Wydawnictwo Naukowe PWN [Polish Scientific Publishers], Warszawa.

32. Paliszkiewicz J., Koohang A., Gołuchowski J., Nord J. H. (2014), Management trust, organizational trust, and organizational performance: advancing and measuring a theoretical model, "Management and Production Engineering Review", Vol. 5, Issue 1, pp. 32-41.

33. Paliszkiewicz J., Koohang A., Nord J. H. (2014), Management trust, organizational trust, and organizational performance: Empirical validation of an 
instrument, "Online Journal of Applied Knowledge Management", Vol. 2, Issue 1, pp. 28-39.

34. Romanowska M., Trocki M. (ed.) (2002), Przedsiębiorstwo Partnerskie [Partner Comapny], Difin, Warszawa.

35. Rudzewicz A. (2016), Pomiar zaufania wewnętrznego w organizacji [Measurement of Trust Internal Organization], "Studia i Prace WNEiZ US" ["Studies and Works of FoEaM US"], No. 43 T. 2. Zarządzanie [Management], pp. 239-248.

36. Sankowska A. (2009), Diagnoza poziomu zaufania pomiędzy przedsiębiorstwami [Diagnosis of trust level of trust between companies], "Przegląd Organizacji" ["Organization Review"], No. 7-8, pp. 30-34.

37. Sankowska A. (2011), Wptyw zaufania na zarzadzanie przedsiębiorstwem. Perspektywa wewnatrzorganizacyjna [Effect of trust on company management. Intraorganisational perspective], Difin, Warszawa.

38. Shapiro S. P. (1987), The social control of impersonal trust, "American Journal of Sociology", No. 93 (3), pp. 623-658.

39. Skalik J. (2012), Ewolucja metodycznego wspomagania procesu zarządzania zmianami w organizacjach [Evolution of methodical support of the management process of changes in organisations], [in:] G. Bełz, S. Cyfert (ed.), Strategie $i$ mechanizmy odnowy przedsiębiorstw [Renewal strategies and mechanisms of companies], Wydawnictwo Uniwersytetu Ekonomicznego we Wrocławiu [Publishing House of Wrocław University of Economics], Wrocław, „Prace Naukowe" ["Scientific Papers"], No. 276, pp. 28-37.

40. Skalik J., Wierzbic A. (2013), Zarządzanie wiedza jako źródło sukcesu małej firmy [Knowledge management as a source of success of a small company], [in:] G. Bełz, M. Hopej, A. Zgrzywa-Ziemak (ed.), Wiedza w zarządzaniu wspótczesna organizacja [Knowledge in the current organisation management], Wydawnictwo Uniwersytetu Ekonomicznego we Wrocławiu [Publishing House of Wrocław University of Economics], Wrocław, „Prace Naukowe” [“Scientific Papers"], No. 299, pp. 94-104.

41. Solomon R.C., Flores F. (2001), Building Trust in Business, Politics, Relationships, and Life, Oxford University Press, New York.

42. Stankiewicz J. (1999), Możliwości wyzwalania i intensyfikowania zachowań twórczych pracowników [Possibilities of triggering and intensifying creative behaviours of employees], "Management", No. 2.

43. Stankiewicz J., Bortnowska H. (2011), Samodoskonalenie szansa na poprawe konkurencyjności pracowników na bankowym rynku pracy (w świetle wyników badań) [Self-improvement as an opportunity to increase competitiveness of employees on banking labour market (research outcomes prespective)], [in:] M. Al.Noorachi (ed.), Wybrane zagadnienia z zakresu zarzadzania przedsiębiorstwem [Selected issues of company management], "Przedsiębiorczość i Zarządzanie" ["Entrepreneurship and Management"], Vol. XII, Issue 3, Wydawnictwo 
Społecznej Wyższej Szkoły Przedsiębiorczości i Zarządzania w Łodzi [Publishing House of the Academy of Management in Łódź], Łódź, pp. 9-21.

44. Stankiewicz J., Łychmus P., Bortnowska H. (2011), Szanse upowszechniania programów etycznych wśród pracowników bankowych poprzez e-learning [Chances of Promotion Ethical Programs Among Bankers Through E-learning], [in:] G. Rosa, A. Smalec, L. Gracz, Marketing przyszłości. Trendy. Strategie. Instrumenty. Marketing $w$ działalności podmiotów rynkowych [Marketing of the future. Trends. Strategies. Instruments. Marketing in the activities of market entities], "Zeszyty Naukowe" ["Scientific Journals"], No. 662, "Ekonomiczne Problemy Usług" ["Economic Problems of Services"] No. 74, Wydawnictwo Naukowe Uniwersytetu Szczecińskiego [Scientific Publishing House of the University of Szczecin], Szczecin, p. 581-593.

45. Stankiewicz J., Moczulska M. (2013), Poprzez walkę $i$ wspótzawodnictwo pracowników do innowacyjnej organizacji (w świetle wyników badań empirycznych) [By the employees' fight and competition to an innovative organisation (in the light of the empirical research results)], [in:] J. Skalik, A. Zabłocka-Kluczka (ed.), Innowacje w zarzadzaniu [Innovations in managements], Wydawnictwo Uniwersytetu Ekonomicznego we Wrocławiu [Publishing House of Wrocław University of Economics], Wrocław, "Prace Naukowe" ["Scientific Papers"], No. 300, pp. 119-130.

46. Stankiewicz J., Moczulska M. (2016), Zachowania pracowników sprzyjajace innowacyjności organizacji w świetle badań [Employees' behaviours promoting organisational innovativeness in the light of research], "Przegląd Organizacji” ["Overview of Organisations"] No. 2, pp. 36-43.

47. Sztompka P. (1998), Trust, distrust and two paradoxes of democracy, "European Journal of Social Theory", vol. 1, No. 1, pp. 19-32.

48. Sztompka P. (1999), Kulturowe imponderabilia szybkich zmian społecznych: zaufanie, lojalność, solidarność [Cultural imponderables of fast social changes: trust, loyalty, solidarity], [in:] P.Sztompka (ed.) Imponderabilia wielkiej zmiany. Mentalność, wartości i więzi społeczne czasów transformacji [Imponderables of the great change. Mentality, values and social ties of the time of transformation], PWN [Polish Scientific Publishers], Warszawa-Kraków.

49. Sztompka P. (2007), Zaufanie. Fundament społeczeństwa [Trust. The foundation of society], Znak [Sign], Kraków.

50. Wójcik-Karpacz A., Karpacz J. (2015), Jak powstrzymywać oportunizm partnera: rola osadzenia w sieci [How to Inhibit a Partner's Opportunism: Role of Network Embeddedness], [in:] R. Krupski (ed.), Zarzadzanie strategiczne. Strategie sieci $i$ przedsiębiorstw w sieci, "Prace Naukowe Wałbrzyskiej Wyższej Szkoły Zarządzania i Przedsiębiorczości" ["Scientific Works of the Higher School of Management and Entrepreneurship in Wałbrzych"], Vol. 32, 2(2015), Wydawnictwo Wałbrzyskiej Wyższej Szkoły Zarządzania 


\section{Management \\ 2017}

Vol. 21, No. 1

i Przedsiębiorczości w Wałbrzychu [Publishing House of the Higher School of Management and Entrepreneurship in Wałbrzych], Wałbrzych.

51. Zaheer A., McEvily B., Perrone V. (1998), Does trust matter? Exploring the effects of interorganizational and interpersonal trust on performance, “Organization Science", No. 9 (2), pp. 141-159.

52. Zand D.E. (1972), Trust and managerial problem solving, "Administrative Science Quarterly", No. 17 (2), pp. 229-239.

53. Zieliński T. (2012), Zaufanie jako regulator decyzji ekonomicznych (analiza literatury) [Trust as Regulator of Economic Decision Making], "Management and Business Administration. Central Europe" 4/2012 (117), pp. 73-91. 